\title{
Initial Growth of Corn Using Human Urine, Cassava Wastewater and Cattle Manure as Source of Nutrients
}

\author{
J. G. Ramos ${ }^{1}$, Vera Lúcia Antunes de Lima ${ }^{1}$, Leandro Fabrício Sena ${ }^{1}$, Narcísio Cabral de Araújo ${ }^{1}$, \\ Mariana de Oliveira Pereira ${ }^{1}$, Márcia Cristina de Araújo Pereira ${ }^{1} \&$ Vitória Ediclécia Borges ${ }^{1}$ \\ ${ }^{1}$ Graduate Program in Agricultural Engineering, Federal University of Campina Grande, Parraiba, Brazil \\ Correspondence: Leandro Fabrício Sena, Graduate Program in Agricultural Engineering, Federal University of \\ Campina Grande, Street Campina Grande, University District, Paraiba, Brazil. Tel: 55-83-9-9615-3281. E-mail: \\ leandrofsena@hotmail.com
}

Received: September 4, 2017

Accepted: October 11, $2017 \quad$ Online Published: October 15, 2017

doi:10.5539/jas.v9n11p275

URL: https://doi.org/10.5539/jas.v9n11p275

The research is financed by CAPES (Coordenação de Aperfeiçoamento de Pessoal de Nivel Superio).

\begin{abstract}
The present study aimed to analyze the initial growth of the corn hybrid AG 1051 cultivated in soil fertilized with human urine, cassava wastewater and cattle manure. The experimental design was completely randomized with four replicates and eight treatments: T1 (Control - without fertilization), T2 (HU - Human urine), T3 (CW - Cassava wastewater), T4 (BM - Cattle manure), T5 (BM + HU - Cattle manure + Human urine), T6 (BM + $\mathrm{CW}-$ Cattle manure + Cassava wastewater), $\mathrm{T} 7(\mathrm{HU}+\mathrm{CW}-$ Human urine + Cassava wastewater) and T8 (HU $+\mathrm{CW}+\mathrm{BM}-$ Human urine + Cassava wastewater + Cattle manure). ESI (emergence speed index) and E\% (emergence percentage) were determined by daily counting all seedlings emerged in a period of seven days and, at 15 DAS (days after sowing), plant height was measured. The use of cattle manure led to higher ESI and E\% compared with the other treatments, as well as the variable plant height. For production variables, T5 caused highest increment in shoot dry phytomass and there were no significant differences between treatments for shoot dry phytomass. It was concluded that T4, T6 and T5 led to higher performance in the initial growth stage.
\end{abstract}

Keywords: yellow water, agricultural reuse, Zea Mays L.

\section{Introduction}

Corn (Zea mays L.) is one of the most important crops in the world and, although Brazil is the third largest global producer, it does not stand out in the same way with respect to yield. The yield in Brazil is considered as low compared with other producing countries. Such poor performance is mainly related to factors such as mineral nutrition, population density and plant arrangement (Cruz et al., 2008).

Regarding mineral nutrition, nitrogen and phosphorus are the most required nutrients by the corn crop and are the ones available at lowest concentrations in the soil (Sousa et al., 2017). These macronutrients directly influence grain production, because they positively act on the number of grains per ear and individual grain weight (Valderrama et al., 2011). Phosphorus deficiency influences nitrogen absorption, causing reduction in leaf growth and compromising grain formation and development (Silva et al., 2009; Oliveira et al., 2012, Martin et al., 2011).

Considering the agro-industrial development and generation of large amounts of organic residues with high polluting potential to the environment (330 million tons, on average) along the productive chain of various products, the reuse of these residues in agriculture has been considered as one way to attenuate the environmental impacts inherent to their disposal in the environment, besides pointing to a new, promising use of these residues (Morais et al., 2012; Virmond, 2011; Damasceno et al., 2003; Magalhães et al., 2014).

The use of increasingly higher doses of chemical fertilizers has been intensified in order to increase corn yield. In this context, the use of organic fertilizers in crops becomes an alternative capable of reducing the expressive amounts of mineral fertilizers applied to the soil. 
Among various residues generated by agro-industrial activities, cassava waste-water is a residue from the processing of cassava roots (Manihot esculenta Crantz) and has potential in the utilization as source of nutrients to soil and plants, being able to supply particularly potassium $(\mathrm{K})$, nitrogen $(\mathrm{N})$, magnesium $(\mathrm{Mg})$, phosphorus (P), calcium (Ca) and sulfur (S) (Cardoso et al., 2009). It is an effluent with high organic load (BOD and COD) and toxic cyanogenic glucosides such as linamarin (Campos et al., 2006).

Another effluent that has been studied with potential in agricultural production is human urine or yellow water. This effluent is an aqueous solution containing sodium chloride $(\mathrm{NaCl})$, urea $\left[\mathrm{CO}\left(\mathrm{NH}_{2}\right)_{2}\right]$, potassium $(\mathrm{K})$, calcium $(\mathrm{Ca})$, sulfate $\left(\mathrm{SO}_{4}\right)$ and phosphorus $(\mathrm{P})$, which is available as polyphosphate $\left(\mathrm{H}_{2} \mathrm{PO}^{4-}\right.$ or $\left.\mathrm{HPO}_{4}{ }^{2-}\right)(\mathrm{Lind}$, Ban, \& Bydén, 2001).

Among human excrements, human urine contributes with about $90 \%$ of $\mathrm{N}, 50-65 \%$ of $\mathrm{P}$ and $50-80 \%$ of $\mathrm{K}$ (Heinonen \& Van Wijk, 2005). Authors such as Barreto et al. (2014) and Magalhães et al. (2014) evaluated the effects of using cassava waste-water as source of nutrients in agricultural production and observed significant results up to a certain volume threshold. Akpan-Idiok et al. (2012) and Araújo et al. (2015) observed increments in plant green matter applying human urine through irrigation.

Hence, this study aimed to evaluate the growth of the corn hybrid AG 1051 in soil fertilized with human urine, cattle manure and cassava waste-water wastewater as source of nutrients in protected environment.

\section{Materials and Methods}

The study was carried out at the Campus I of the Federal University of Campina Grande (UFCG), Campina Grande-PB, Brazil ( $7^{\circ} 12^{\prime} 58.67^{\prime \prime} \mathrm{S} ; 35^{\circ} 54^{\prime} 35.71^{\prime \prime} \mathrm{W} ; 550 \mathrm{~m}$ asl.), from April to May 2017. The soil used in the experiment was classified as Regolithic Neosol with the following physical-chemical characteristics: $\mathrm{pH}$ in water $(1: 2: 5)=5.58 ; \mathrm{EC}=0.56 \mathrm{mmhos} \mathrm{cm}^{-1} ; \mathrm{Al}=0.00 \mathrm{cmolc} \mathrm{dm}^{-3} ; \mathrm{Mg}=2.78 \mathrm{cmolc} \mathrm{dm}^{-3} ; \mathrm{Ca}=9.07 \mathrm{cmolc} \mathrm{dm}^{-3} ; \mathrm{K}=$ $0.33 \mathrm{cmolc} \mathrm{dm}^{-3} ; \mathrm{Na}=1.64 \mathrm{cmolc} \mathrm{dm}^{-3} ; \mathrm{P}=3.98 \mathrm{cmolc} \mathrm{dm}^{-3} ; \mathrm{S}=13.72 \mathrm{cmolc} \mathrm{dm}^{-3}$; organic carbon $=1.70 \%$; organic matter $=2.93 \%$ and soil bulk density $=1.28 \mathrm{~g} \mathrm{~cm}^{-3}$.

Maximum and minimum temperatures and relative air humidity inside the greenhouse in the studied period are presented in Figure 1. Temperature was daily recorded, always at 9:00 a.m., using a digital thermo-hygrograph.

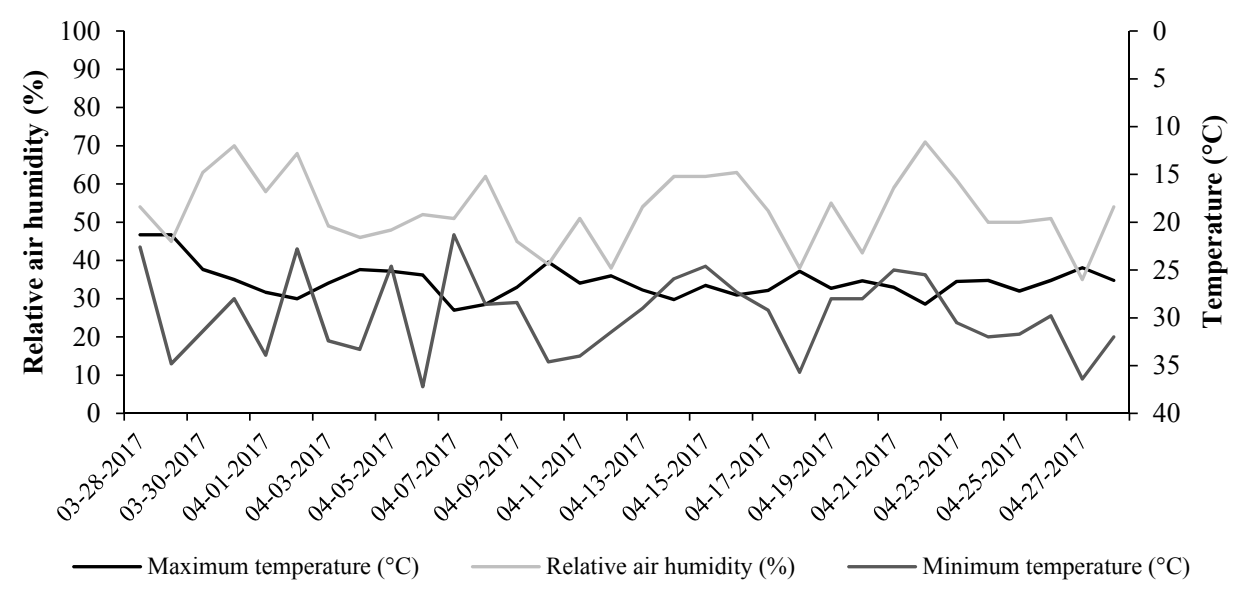

Figure 1. Maximum and minimum temperatures and relative air humidity inside the greenhouse

Plants were grown in a $640-\mathrm{m}^{2}$ arched greenhouse with metal structure, covered by $150-\mu \mathrm{m}$-thick low-density polyethylene and, on the sides, by $80 \%$ shade cloth.

The experiment used the forage corn double-cross hybrid AG 1051, which has high potential for green corn and silage production. Its main features are: semi-early cycle, average of 115 days for silage and 144 days for grain harvest; high grain production and green matter with high digestibility.

The experiment was set using $20-\mathrm{L}$ pots filled with a $0.04-\mathrm{kg}$ layer of crushed stone $\left(\mathrm{n}^{\circ} 03\right)$, covered with a geotextile and $15.5 \mathrm{~kg}$ of soil, to facilitate drainage. A 33-mm-diameter hole was made at the bottom of each pot and a transparent flexible hose was connected for drainage. A geotextile was placed on this hole to facilitate drainage and prevent its clogging. After filling the pots, the soil was brought to field capacity. 
The experimental units were arranged at spacing of $50 \mathrm{~cm}$ between pots and 50 between rows. Sowing was directly performed in the pots, by planting 10 seeds in each. At 15 days after emergence (DAE), thinning was made to maintain four plants per pot.

Along crop development, irrigation was daily applied based on drainage lysimetry, according to the methodology proposed by Bernardo et al. (2008), to prevent the crop from suffering drought stress. To quantify the volume drained in each irrigation event, a 2-L tank was connected to the tip of each drain, to store the drained volume 24 hours after each irrigation event. Irrigations were performed using rainwater, stored in $5-\mathrm{m}^{3}$ boxes, with electrical conductivity (ECw) of $0.04 \mathrm{dS} \mathrm{m}^{-1}$.

The experimental design was completely randomized (CRD) with eight treatments and four replicates, totaling 32 experimental units. Treatments consisted of individual and combined doses of human urine, cassava wastewater and aged cattle manure, defined as follows: T1 (Control - without fertilization), T2 (HU - Human urine), T3 (CW - Cassava wastewater), T4 (BM - Cattle manure), T5 (BM + HU - Cattle manure + Human urine), $\mathrm{T} 6(\mathrm{BM}+\mathrm{CW}-$ Cattle manure + Cassava wastewater $), \mathrm{T} 7(\mathrm{HU}+\mathrm{CW}-$ Human urine + Cassava wastewater $)$ and $\mathrm{T} 8(\mathrm{HU}+\mathrm{CW}+\mathrm{BM}-$ Human urine + Cassava wastewater + Cattle manure $)$.

The human urine used in the study was collected from three households in the municipality of Campina Grande-PB and subjected to previous treatment through anaerobic digestion to inactivate possible pathogenic microorganisms. Urine was stored in a hermetically sealed 20-L tank for a period of 60 days. This treatment promotes increase of $\mathrm{pH}$ (Table 1) in the human urine and, therefore, inactivation of possible pathogenic microorganisms present in the effluent, except for helminth eggs. Presence of helminth eggs only occurs when there is cross contamination, when direct contact with feces occurs during effluent collection.

Cassava wastewater was collected in a starch production plant in the municipality of Puxinanã-PB and subjected to anaerobic digestion in a hermetically sealed $85-\mathrm{L}$ container. A $5-\mathrm{cm}$ air column was left between the effluent and the edge of the container. The lid was connected by a hose to a PET (polyethylene terephthalate) bottle with water height of $5 \mathrm{~cm}$ to release gases generated during effluent digestion, especially hydrocyanic acid, which is released in large amounts due to the presence of a cyanogenic glucoside known as linamarin, after hydrolyzation (Table 1).

Table 1. Physical-chemical characterization of human urine and cassava wastewater after anaerobic digestion

\begin{tabular}{|c|c|c|c|c|c|c|c|}
\hline \multicolumn{8}{|c|}{ Parameters } \\
\hline & TKN & $\mathrm{NH}_{3}-\mathrm{N}$ & $\mathrm{P}-\mathrm{PO}_{4}{ }^{-3}$ & $\mathrm{~K}$ & $\mathrm{Na}$ & $\mathrm{pH}$ & EC \\
\hline & |------ & - & $\mathrm{g} \mathrm{L}^{-1}$ & --------- & ----------- & - & $--\mathrm{mS} \mathrm{cm}^{-1}$ \\
\hline $\mathrm{HU}$ & 8.706 & 6.737 & 0.325 & 1.097 & 2.455 & 9.32 & 42.7 \\
\hline $\mathrm{CW}$ & 1.680 & 0.933 & 0.338 & 3.948 & 0.138 & 4.73 & 11.75 \\
\hline
\end{tabular}

Note. TKN: Total Kjeldahl Nitrogen; $\mathrm{NH}_{3}-\mathrm{N}$ : Ammoniacal nitrogen; $\mathrm{P}_{-} \mathrm{PO}_{4}^{-3}$ : Soluble orthophosphate; K: Potassium; Na: Sodium; pH: Hydrogen potential; EC: Electrical conductivity; HU: human urine; CW: Cassava wastewater.

The effluent volume applied in each experimental unit was estimated according to the recommendation for fertilization of Novais et al. (1991), based on the macronutrients present at highest concentration in human urine and cassava wastewater, total nitrogen and potassium, respectively. Hence, nitrogen concentration was considered for human urine whereas potassium was the reference element in cassava wastewater.

The applied volumes were equal to $200 \mathrm{~mL}$ in treatments with human urine, corresponding to $28.30 \mathrm{~m}^{3} \mathrm{ha}^{-1}$, and to $590 \mathrm{~mL}$ in treatments with cassava wastewater, equivalent to $83.5 \mathrm{~m}^{3} \mathrm{ha}^{-1}$.

The cattle manure also used as biofertilizer was aged, i.e., it subjected to a period of rest so that all organic matter was stabilized and nutrients became readily available to be diluted in the soil solution. Its chemical characterization is presented in Table 2 . 
Table 2. Characterization of aged cattle manure

\begin{tabular}{|c|c|c|c|c|c|c|}
\hline $\mathrm{pH}$ & $\mathrm{EC}$ & $\mathrm{N}$ & $\mathrm{P}$ & $\mathrm{K}$ & $\mathrm{S}$ & $\mathrm{Na}$ \\
\hline - & $--\mathrm{dS} \mathrm{cm}{ }^{-1}--$ & - --- & $-\cdots$ & --- g & --- & 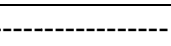 \\
\hline 6.05 & 43.40 & 0.42 & 21.25 & 7.60 & 9.66 & 2.57 \\
\hline
\end{tabular}

Note. pH: Hydrogen potential; EC: Electrical conductivity; N: Total nitrogen; P: Phosphorus; K: Potassium; S: Sulfur; Na: Sodium.

Fifteen days before sowing, aged cattle manure $(5 \%$, based on total soil weight in each pot, equivalent to 0.775 $\mathrm{kg}$ ) was incorporated to the soil, which was maintained close to field capacity in order to promote favorable conditions for incorporation.

Corn was sown fifteen days after basal fertilization, a time necessary for stabilization of its nutrients and evaporation of the hydrocyanic acid present in the cassava wastewater, resulting from linamarin hydrolysis.

To evaluate crop development, after sowing, the number of emerged seedlings was daily monitored until the $7^{\text {th }}$ day, which allowed to determine emergence percentage (E\%) and emergence speed index (ESI), according to the methodology proposed by Maguire (1962).

$$
\mathrm{E} \%=\frac{\mathrm{N}}{\mathrm{A}} \times 100
$$

Where, E\%: emergence percentage; N: total number of emerged seedlings; and A: total number of seeds sown.

$$
\mathrm{ESI}=\left(\frac{\mathrm{N} 1}{\mathrm{DQ} 1}+\frac{\mathrm{N} 2}{\mathrm{DQ} 2}+\ldots+\frac{\mathrm{Nn}}{\mathrm{DQn}}\right)
$$

Where, ESI: emergence speed index; N: number of seedlings on the day of count; and DQ: number of days after sowing.

Growth was evaluated at $15 \mathrm{DAE}$, based on the following parameters: plant height $(\mathrm{PH}, \mathrm{cm})$, measured with a $250-\mathrm{cm}$ tape measure from the soil to the highest organ; stem diameter (SD, cm), measured with a digital caliper (0.05-mm accuracy); and number of leaves (NL), measured through direct count.

Shoot fresh phytomass (SFP) of one plant was determined using an analytical scale (0.01-g accuracy). For shoot dry phytomass (SDP), samples were individually placed in paper bags and dried in forced-air oven at $65^{\circ} \mathrm{C}$ until constant weight.

\section{Results and Discussion}

According to the results for the effects of different types of fertilizers used in basal fertilization, a functional relationship was observed between the treatments, for the individual and combined application of the bio-fertilizers, since the treatment with only cattle manure (T4) led to higher emergence speed index (ESI), compared with the others, with a percent difference of $49.1 \%$ in comparison to T6 $(\mathrm{BM}+\mathrm{CW})$.

Such difference in ESI may have been favored by the fact that cassava wastewater is a residue with highly cyanogenic potential when hydrolyzed, an effect that was observed on all treatments in which cassava wastewater was used with one of the fertilizers (Figure 1A).
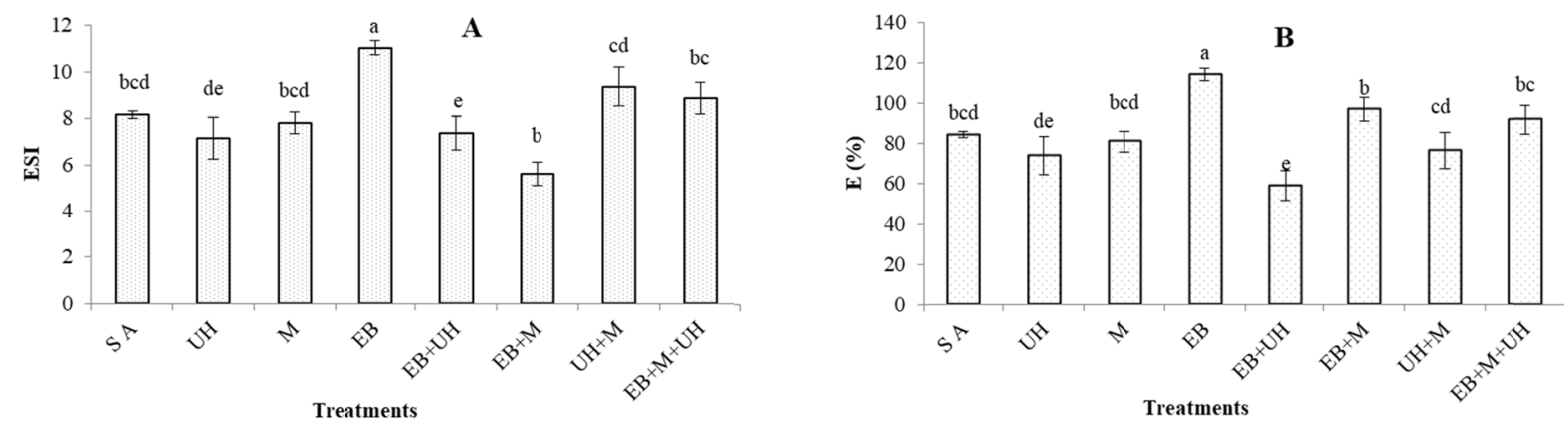


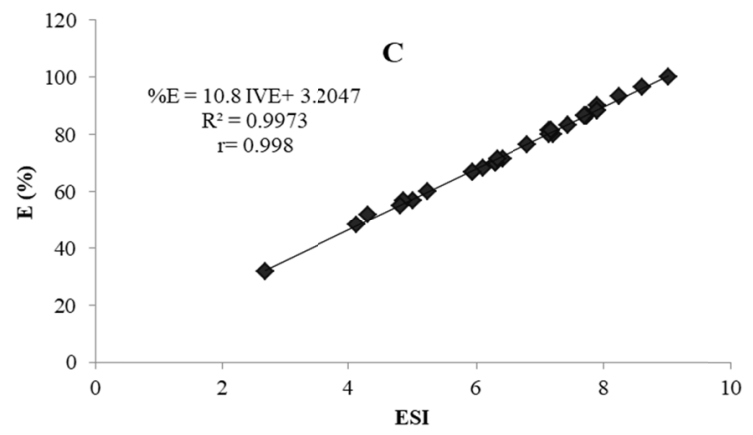

Figure 2. Emergence speed index of Zea mays L. as function of fertilization with cattle manure, human urine and cassava wastewater as source of nutrients

Regarding emergence percentage (E\%), the results indicate a behavior similar to that of ESI for the fertilization using cattle manure (T4), with a percent superiority of $48.23 \%$ in comparison to seedlings cultivated in soil fertilized with $\mathrm{T} 5(\mathrm{BM}+\mathrm{HU})$, which was the treatment with highest number of emerged seedlings in relation to the total number of seeds sown (Figure 1B).

There is strong positive correlation between the variables ESI and E\%, with Pearson coefficient of 0.998 and $\mathrm{R}^{2}$ of 0.997 (Figure 1C), evidencing that both variables are strongly correlated, showing very similar statistical results.

These results indicate the efficiency of basal fertilization of corn crop using cattle manure in the emergence, because the use of cattle manure, among other organic residues, is the best alternative to improve the physical and chemical conditions of these soils and, in addition, it contains 30 to 58\% of organic matter (Pereira et al., 2002; Ramos et al., 2010; Ferreira et al., 2012). These results were similar to the present study that the use of cattle manure showed efficiency in emergence speed index and emergence percentage variables.

The analysis of variance showed significant differences between the means due to the different types of basal fertilization for all variables. Application of cattle manure led to better results of growth parameters: plant height, stem diameter and number of leaves at 15 DAE (Table 3).

Table 3. Corn growth in protected environment as a function of different types of basal fertilization

\begin{tabular}{|c|c|c|c|c|c|}
\hline SV & PH (cm) & SD (cm) & NL & SFP (g) & SDP (g) \\
\hline T1-Control & $32.06 \mathrm{bc}$ & $4.37 \mathrm{c}$ & $4.75 \mathrm{bcd}$ & $5,5950 \mathrm{~b}$ & $1,5450 \mathrm{a}$ \\
\hline $\mathrm{T} 2-\mathrm{HU}$ & $28.63 \mathrm{c}$ & $4.51 \mathrm{c}$ & $4.00 \mathrm{~d}$ & $3,6875 \mathrm{c}$ & $1,2425 \mathrm{a}$ \\
\hline $\mathrm{T} 3-\mathrm{CW}$ & $31.00 \mathrm{bc}$ & $4.33 \mathrm{c}$ & $4.50 \mathrm{~cd}$ & $5,0800 \mathrm{~b}$ & $1,2900 \mathrm{a}$ \\
\hline $\mathrm{T} 4-\mathrm{BM}$ & $47.50 \mathrm{a}$ & $5.88 \mathrm{a}$ & $5.75 \mathrm{a}$ & $5,6700 \mathrm{~b}$ & $1,3425 \mathrm{a}$ \\
\hline $\mathrm{T} 5-\mathrm{BM}+\mathrm{HU}$ & $13.37 \mathrm{~d}$ & $4.60 \mathrm{bc}$ & $5.00 \mathrm{abc}$ & $8,6325 \mathrm{a}$ & $1,4225 \mathrm{a}$ \\
\hline $\mathrm{T} 6-\mathrm{BM}+\mathrm{CW}$ & $38.00 \mathrm{~b}$ & $5.58 \mathrm{ab}$ & $5.50 \mathrm{ab}$ & $5,5950 \mathrm{~b}$ & $1,1050 \mathrm{a}$ \\
\hline $\mathrm{T} 7-\mathrm{HU}+\mathrm{CW}$ & $27.65 \mathrm{c}$ & $4.11 \mathrm{c}$ & $4.75 \mathrm{bcd}$ & $5,7300 \mathrm{~b}$ & $1,3050 \mathrm{a}$ \\
\hline $\mathrm{T} 8-\mathrm{BM}+\mathrm{HU}+\mathrm{CW}$ & $36.00 \mathrm{bc}$ & $4.59 \mathrm{bc}$ & $5.00 \mathrm{abc}$ & $5,7525 \mathrm{~b}$ & $1,3350 \mathrm{a}$ \\
\hline $\mathrm{CV}(\%)$ & 11.71 & 9.33 & 8.58 & 7,90 & 15,94 \\
\hline Fc value & $27.64 *$ & $8.148^{*}$ & $6.832 *$ & $36.543 *$ & $1.479 *$ \\
\hline
\end{tabular}

Note. Means followed by different lowercase letters in the columns of each parameter differ by Tukey test at 0.05 probability level $(\mathrm{P}<0.05)$. CV: Coefficient of variation. Fc: Calculated F.

Silva et al. (2007) evaluated corn yield in different production systems and concluded that the organic system, with cattle manure fertilization, is superior to the mineral and no-fertilization systems, because the use of aged bovine biofertilizer improves soil physical, chemical and biological properties (Freitas \& Souza, 2009).

The use of human urine (T2) and cassava wastewater (T3) did not lead to good results, compared with combined or individual treatments with cattle manure. There were increments of $39.97 \%, 23.29 \%$ and $30.43 \%$ in plant height, stem diameter and number of leaves, respectively, between corn plants grown in soils fertilized cattle manure and with human urine. 
In a study conducted by Idiok et al. (2012), human urine was used as source of nutrients for the okra crop, which showed significant increase in yield compared with the use of inorganic fertilizer or no use of fertilizer.

Magalhães et al. (2011), studying the initial growth of the corn hybrid AG 1051 subjected to different doses of cassava wastewater, observed that the dose equivalent to $63 \mathrm{~m}^{3} \mathrm{ha}^{-1}$ promoted increase in stem diameter and number of leaves, while the dose equivalent to $75.63 \mathrm{~m}^{3} \mathrm{ha}^{-1}$ led to significant increase in plant height.

Evaluating the effect of foliar application of cassava wastewater doses on corn development, Araújo et al. (2012) found that the highest dose, $75 \%$ ( $750 \mathrm{~mL}$ of cassava wastewater $+250 \mathrm{~mL}$ of water), was efficient as source of foliar fertilization for corn, guaranteeing significant gain of fresh matter, plant height and number of leaves. However, these authors emphasize that, although the $75 \%$ cassava wastewater dose guaranteed better plant development, foliar application is only recommended up to the dose of $50 \%(500 \mathrm{~mL}$ of cassava wastewater + $500 \mathrm{~mL}$ of water), because higher values caused severe injuries on corn leaves due to the hydrocyanic acid still present in it.

Combinations of cattle manure + cassava wastewater or cattle manure + human urine did not lead to good results in comparison to corn cultivation in soil fertilized only with aged cattle manure. While corn plants cultivated in soil fertilized with T4 showed plant height of $52 \mathrm{~cm}$, stem diameter of $6.88 \mathrm{~mm}$ and 6 leaves, those cultivated in soil fertilized with T2 showed plant height of $29 \mathrm{~cm}$, stem diameter of $4.66 \mathrm{~mm}$ and 4 leaves, and plant height of $39.5 \mathrm{~cm}$, stem diameter of $4.5 \mathrm{~mm}$ and 5 leaves, thus evidencing that the combination of cattle manure with human urine and/or cassava wastewater decreased the efficiency of cattle manure as bio-fertilizer.

There were significant differences between treatments regarding SFP. For the initial growth of corn, the lowest value $(3,6875 \mathrm{~g})$ was observed under fertilization with only T2 (human urine), while the treatment T5 (human urine + cattle manure) led to the best result in gain of weight, $8,6325 \mathrm{~g}$, i.e., there was a percent increment of $42.71 \%$ from T2 to T5. There were no significant statistical differences for this variable due to the other treatments. According to Leite et al. (2003), the combination of substrates with cattle manure has been object of study as an important management tool for the improvement in soil quality and saving for small farmers.

For SDP production with the application of bio-fertilizers, the values indicated that there were no significant differences between treatments by Tukey test at 0.05 probability level. According to Almeida et al. (1998), the increase of dry plant biomass is reflected by the yield of the crop, so plants with higher initial dry matter increase and dry matter are linked to the use of solar radiation in the production of photo-assimilates that are available for culture.

\section{Conclusion}

Aged cattle manure as basal fertilization promotes higher increments in the initial growth variables of the corn hybrid AG 1051.

Combinations of fertilizations with cattle manure + cassava wastewater and cattle manure + human urine also favored the initial growth of the corn hybrid AG 1051.

The use of cattle manure + human urine in corn fertilization led to highest fresh phytomass accumulation in the vegetative stage.

The different organic fertilizations with aged cattle manure, cassava wastewater and human urine, combined or individually, did not influence the dry phytomass of the corn hybrid 1051.

\section{References}

Akpan-Idiok, A. U., Udo, I. A., \& Braide, I. E. (2012). The use of human urine as an organic fertilizer in the production of okra (Abelmoschus esculentus) in South Eastern Nigeria. Resources, Conservation and Recycling, 62, 14-20. https://doi.org/10.1016/j.resconrec.2012.02.003

Araújo, N. C., Amorim C. M., Oliveira, R., Meira, C. M. B. S., \& Oliveira, S. J. C. (2015). Cultivo hidropônico de milho fertirrigado com urina humana como fonte alternativa de nutrientes. IRRIGA, 20(4), 718. https://doi.org/10.15809/irriga.2015v20n4p718

Araújo, N. C., Ferreira, T. C., Oliveira, S. J. C., Gonçalves, C. P., \& de Araújo, F. A. C. (2012). Avaliação do uso de efluente de casas de farinha como fertilizante foliar na cultura do milho (Zea mays L.). Revista Engenharia na Agricultura, 20, 340-349. https://doi.org/10.13083/1414-3984.v20n04a06

Araújo, N. C., Lima, V. L. A., Andrade, E. M. G., Oliveira, S. J. C., Cardoso, J. A. F., \& Sena, L. F. (2017). Crescimento inicial de feijão Vigna fertirrigado com urina e manipueira. Revista Espacios, Caracas, 38(13), 21-31. 
Barreto, M. T. L., Magalhães, A. G., Rolim, M. M., Pedrosa, E. M. R., Duarte, A. S., \& Tavares, U. E. (2014). Desenvolvimento e acúmulo de macronutrientes em plantas de milho biofertilizadas com manipueira. Revista Brasileira de Engenharia Agrícola e Ambiental, 18, 487-494. https://doi.org/10.1590/ S1415-43662014000500004

Bernardo, S., Mantovani, E. C., \& Soares, A. A. (2008). Manual de Irrigação (p. 611). Viçosa, UFV.

Campos, A. T., Daga, J., Rodrigues, E. E., Franzener, G., Suguy, M. M., \& Syperrecker, V. I. G. (2006). Tratamento de águas residuárias de fecularia por meio de lagoas de estabilização. Engenharia Agrícola, 26, 235-242. https://doi.org/10.1590/S0100-69162006000100026

Cardoso, E., Cardoso, D., Cristiano, M., Silva, L., Back, A. J., Bernadim, A. M., \& Paula, M. M. S. (2009). Use of Manihot esculenta, crantz processing residue as biofertilizer in corn crops. Research Journal of Agronomy, 3, 1-8.

Cruz, S. C. S., Pereira, F. R. S, Bicudo, S. J., Albuquerque, A. W., Santos, J. R., \& Machado, C. G. (2008). Nutrição do milho e da Brachiaria decumbens cultivado em consórcio em diferentes preparos do solo. Acta Scientiarum Agronomy, 30(05), 733-739. https://doi.org/10.4025/actasciagron.v30i5.5975

Damasceno, S., Cereda M. P., Pastore, G. M., \& Oliveira, J. G. (2003). Production of volatile compounds by Geotrichum fragans using cassava wastewater as substrate. Process Biochemistry, 39, 411-414. https://doi.org/10.1016/S0032-9592(03)00097-9

De Sousa, I. M., Rocha, D. R. R., Cunha, C. S. M., Gonçalves, I. C. R., \& Castro, J. I. A. (2017). Adubação nitrogenada e modos de disponibilização de micronutrientes na produção de milho verde. Agropecuária Científica no Semiárido, 13(1), 15-21.

Ferreira, T. C., Silva, K. E., Souza, J. T. A., \& Oliveira, S. J. C. (2012). Produção de gergelim Sesamum indicum L. orgânico no agreste paraibano. Revista de Biologia e Farmácia, 7(2), 112-118.

Fittschen, I., \& Hahn, H. H. (1998). Characterization of the municipal wastewater parameters human urine and preliminary comparison with liquid cattle excretion. Water Science and Technology, Carlsruhe, 38(6), 9-16.

Francis, C. A., Rutger, J. N., \& Palmer, A. F. E. (1969). A rapid method for plant leaf area estimation in maize (Zea mays L.). Crop Science, Ontario, 9, 537-539. https://doi.org/10.2135/cropsci1969.0011183X00090 $0050005 \mathrm{x}$

Freitas, G. A., \& Souza, C. R. (2009). Desenvolvimento de plântulas de sorgo cultivadas sob elevadas concentrações de adubações orgânica no sulco de plantio. In II Congresso Latino Americano de Agroecologia, 9, 12 November, Curitiba-PR.

Heinonen, T., H., \& Van Wijk, S. C. (2005). Human excreta for plant production. Bioresource Technology, Rockville, 96, 403-411. https://doi.org/10.1016/j.biortech.2003.10.036

Inoue, K. R. A., Souza, C. F., Matos, A. T., Santos, N. T., \& Alves, E. E. N. (2010). Características do solo submetido a tratamentos com biofertilizantes obtidos na digestão da manipueira. Tecnologia \& Ciência Agropecuária, 4, 47-52.

Leite, L. F. C., Mendonca, E. S., Neves, J. C. L., Machado, P. L. O. A., \& Galvao, J. C. C. (2003). Estoques de totais de carbono orgânico e seus compartimentos em argissolo sob floresta e sob milho cultivado com adubação mineral e orgânica. Revista Brasileira de Ciência do Solo, Viçosa, 27, 821-832. https://doi.org/ 10.1590/S0100-06832003000500006

Lind, B., Ban, Z., \& Bydén, S. (2001). Volume reduction and concentration of nutrients in human urine. Ecological Engineering, Goteborg, 16(4), 561-566. https://doi.org/10.1016/S0925-8574(00)00107-5

Magalhães, A. G., Rolim, M. M., Duarte, A. D. S., Neto, E. B., Tabosa, J. N., \& Pedrosa, E. M. (2014). Desenvolvimento inicial do milho submetido à adubação com manipueira. R. Bras. Eng. Agríc. Ambiental, 18(7), 675-681. https://doi.org/10.1590/S1415-43662014000700001

Maguire, J. D. (1962). Speed of germination aid in selection and evaluation for seedling emergence and vigor. Crop Science, Madison, 2(2), 176-177. https://doi.org/10.2135/cropsci1962.0011183X000200020033x

Martin, T. N., Pavinato, P. S., Silva, M. R., Ortiz, S., \& Bertonceli, P. (2011). Fluxo de nutrientes em ecossistemas de produção de forragens conservadas (pp. 173-219). In Simpósio de Produção e Utilização de Forragens Conservadas, 4, 2011, Maringá. Anais... Maringá: UEM, Departamento de Zootecnia. 
Moraes, M. T., Silva, V. R., \& Arnuti, F. (2012). Resíduos líquidos de efluentes de agroindústria de carnes na produtividade de girassol. Enciclopédia Biosfera, 8, 843-853.

Novais, R. F., Neves, J. C. L., \& Barros, N. F. (1991). Ensaio em ambiente controlado. In A. J. Oliveira (Ed.), Métodos de pesquisa em fertilidade do solo (pp. 189-253). Brasília: Embrapa-SEA.

Oliveira, M. A., Zucareli, C., Brzezinski, C. R., Ferreira, A. S., Domingues, A. R., \& Spolaor, L. T. (2012). Componentes de Produção e Produtividade do Milho em Resposta a Doses de Fósforo e Inoculação com Pseudomonas fluorescens (pp. 1549-1555). In Congresso Nacional de Milho e Sorgo, 29, 2012, Águas de Lindóia. Anais... Sete Lagoas: ABMS/Embrapa Milho e Sorgo.

Pereira, J. R., Beltrão, N. E. M., Arriel, N. H.C., \& Silva, E. S. B. (2002). Adubação Orgânica do Gergelim no Seridó Paraibano. Revista Brasileira de Oleaginosas e Fibrosas, 6(3), 599-608.

Ramos, J. P. C., Júnior, J. N. S. M., Souza, F. F., Fernandes, J. D., \& Lima, V. I. (2010). Comportamento do número de frutos do gergelim (Sesamum indicum) sob diferentes quantidades de esterco bovino (pp. 509-513). In IV Congresso Brasileiro de Mamona \& I Simpósio Internacional de Oleaginosas Energéticas, João Pessoa-PB, 2010. Anais ... Campina grande: Embrapa Algodão.

Silva, E. C., Muraoka, T., Villanueva, F. C. A., \& Espinal, F. S. C. (2009). Aproveitamento de nitrogênio pelo milho, em razão da adubação verde, nitrogenada e fosfatada. Pesquisa Agropecuária Brasileira, Brasília, 44(2), 118-127. https://doi.org/10.1590/S0100-204X2009000200002

Silva, R. G., Galvão, J. C. C., Miranda, G. V., Silva, D. G., \& Arnhold, E. (2007). Produtividade de milho em diferentes sistemas produtivos. Revista Verde de Agroecologia e Desenvolvimento Sustentável, 2(2), 136-141.

Valderrama, M., Buzetti, S., Benett, C. G. S., Andreott, M., Teixeira, F. M. C. M. (2011). Fontes e doses de NPK em milho irrigado sob plantio direto. Pesquisa Agropecuária Tropical, Goiânia, 41(2), 254-263. https://doi.org/10.5216/pat.v41i2.8390

Virmond, E. (2011). Utilização de resíduos agroindustriais como fonte alternativa de energia (p. 264). Tese de Doutorado. Universidade Federal de Santa Catarina, Florianópolis.

\section{Copyrights}

Copyright for this article is retained by the author(s), with first publication rights granted to the journal.

This is an open-access article distributed under the terms and conditions of the Creative Commons Attribution license (http://creativecommons.org/licenses/by/4.0/). 